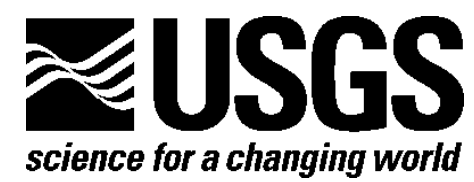

\title{
Emergency Assessment of Post-Fire Debris-Flow Hazards for the 2013 Mountain Fire, Southern California
}

By Dennis M. Staley, Joseph E. Gartner, Greg M. Smoczyk, and Ryan R. Reeves

Open-File Report 2013-1249

U.S. Department of the Interior

U.S. Geological Survey 


\section{U.S. Department of the Interior \\ SALLY JEWELL, Secretary}

\section{U.S. Geological Survey \\ Suzette M. Kimball, Acting Director}

U.S. Geological Survey, Reston, Virginia: 2013

For more information on the USGS-the Federal source for science about the Earth,

its natural and living resources, natural hazards, and the environment-visit

http://www.usgs.gov or call 1-888-ASK-USGS

For an overview of USGS information products, including maps, imagery, and publications, visit $h$ ttp://www.usgs.gov/pubprod

To order this and other USGS information products, visit $h$ ttp://store.usgs.gov

Suggested citation:

Staley, D.M., Gartner, J.E., Smoczyk, G.M., and Reeves, R.R., 2013, Emergency assessment of post-fire debris-flow hazards for the 2013 Mountain fire, southern California: U.S. Geological Survey Open-File Report 2013-1249, 13 p., 3 plates, http://pubs.usgs.gov/of/2013/1249/.

Any use of trade, firm, or product names is for descriptive purposes only and does not imply endorsement by the U.S. Government.

Although this information product, for the most part, is in the public domain, it also may contain copyrighted materials as noted in the text. Permission to reproduce copyrighted items must be secured from the copyright owner. 


\section{Contents}

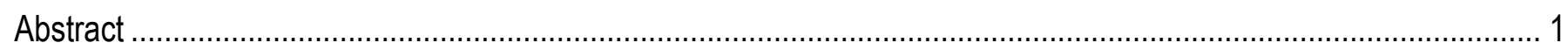

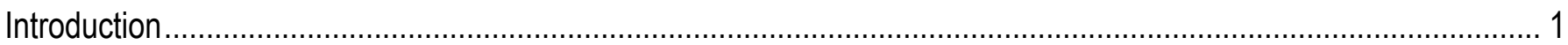

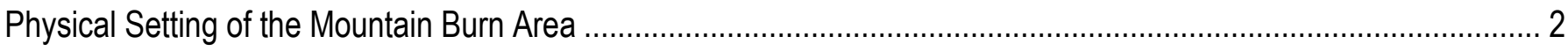

Methods Used To Estimate Debris-Flow Hazards .................................................................................. 5

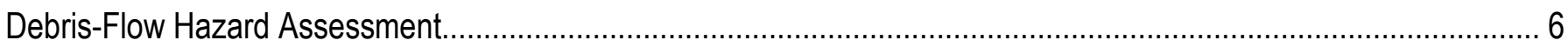

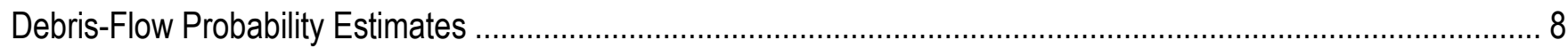

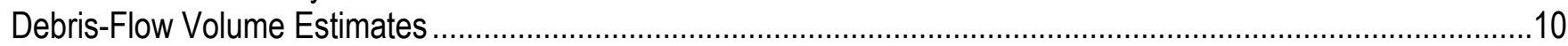

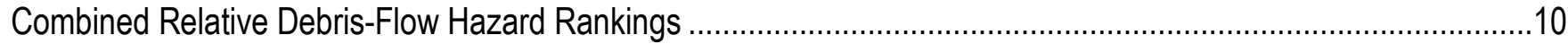

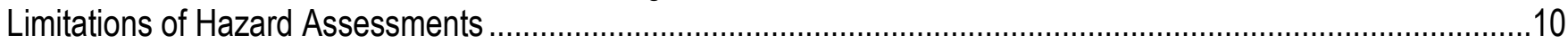

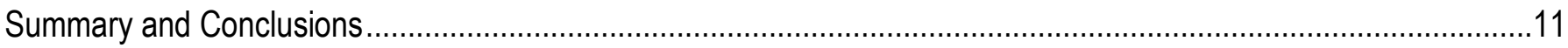

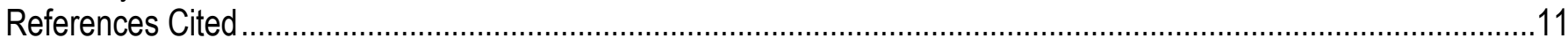

\section{Figures}

Figure 1. Overview map of the Mountain fire burn area near Palm Springs, California, USA ............................... 3

Figure 2. Burned Area Reflectance Classification (BARC) burn severity map of the Mountain fire burn area near

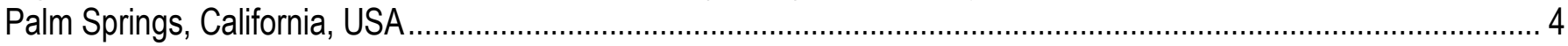

\section{Tables}

Table 1. Basin outlet locations (UTM Zone 11 NAD83, Meters), morphometric variables, rainfall characteristics, and model predictions for the 14 defined watersheds in the Mountain burn area.

Table 2. Summary of the total percentage of stream length per basin within each probability, volume and combined hazard ranking for the Mountain burn area

\section{Plates}

Plate 1. Estimated probability of post-fire debris flows in the area burned by the 2013 Mountain fire, southern California. link

Plate 2. Estimated volume of post-fire debris flows in the area burned by the 2013 Mountain fire, southern California. link

Plate 3. Combined post-fire debris-flow hazard for the area burned by the 2013 Mountain fire, southern California link 


\section{Conversion Factors and Datums}

\begin{tabular}{lcl}
\hline \multicolumn{1}{c}{ Multiply } & By & \multicolumn{1}{c}{ To obtain } \\
\hline millimeter $(\mathrm{mm})$ & 0.03937 & inch (in.) \\
meter $(\mathrm{m})$ & 3.281 & foot $(\mathrm{ft})$ \\
kilometer $(\mathrm{km})$ & 0.6214 & mile $(\mathrm{mi})$ \\
\hline & Area & \\
\hline hectare $(\mathrm{ha})$ & 2.471 & acre \\
square kilometer $\left(\mathrm{km}^{2}\right)$ & 247.1 & acre \\
square kilometer $\left(\mathrm{km}^{2}\right)$ & 0.3861 & square mile $\left(\mathrm{mi}^{2}\right)$ \\
square meter $\left(\mathrm{m}^{2}\right)$ & 10.76 & square foot $\left(\mathrm{ft}^{2}\right)$ \\
\hline & Volume & \\
\hline cubic meter $\left(\mathrm{m}^{3}\right)$ & 35.31 & cubic foot $\left(\mathrm{ft}^{3}\right)$ \\
\hline & Flow rate & \\
\hline millimeter per hour $(\mathrm{mm} / \mathrm{h})$ & 0.03937 & inch per hour $(\mathrm{in} / \mathrm{h})$ \\
\hline
\end{tabular}

Vertical coordinate information is referenced to the North American Vertical Datum of 1988 (NAVD 88).

Horizontal coordinate information is referenced to the North American Datum of 1983 (NAD 83). 


\title{
Emergency Assessment of Post-Fire Debris-Flow Hazards for the 2013 Mountain Fire, Southern California
}

\author{
By Dennis M. Staley, Joseph E. Gartner, Greg M. Smoczyk, and Ryan R. Reeves
}

\begin{abstract}
Wildfire dramatically alters the hydrologic response of a watershed such that even modest rainstorms can produce dangerous flash floods and debris flows. We use empirical models to predict the probability and magnitude of debris flow occurrence in response to a 10-year rainstorm for the 2013 Mountain fire near Palm Springs, California. Overall, the models predict a relatively high probability (60-100 percent) of debris flow for six of the drainage basins in the burn area in response to a 10-year recurrence interval design storm. Volumetric predictions suggest that debris flows that occur may entrain a significant volume of material, with 8 of the 14 basins identified as having potential debrisflow volumes greater than 100,000 cubic meters. These results suggest there is a high likelihood of significant debris-flow hazard within and downstream of the burn area for nearby populations, infrastructure, and wildlife and water resources. Given these findings, we recommend that residents, emergency managers, and public works departments pay close attention to weather forecasts and National Weather Service-issued Debris Flow and Flash Flood Outlooks, Watches and Warnings and that residents adhere to any evacuation orders.
\end{abstract}

\section{Introduction}

The occurrence of debris flows in response to high-intensity rainfall is well documented in recently burned areas of southern California (for example, Eaton, 1935; Campbell, 1975; McPhee, 1989; Cannon and others, 2008, 2010, 2011; Kean and others, 2011; Staley and others, in press). Two recent examples highlight the destructive nature of post-fire debris flows. On December 25, 2003, a highintensity rainstorm initiated debris flows within the Grand Prix and Old burn areas and killed 16 people near San Bernardino, California (Calif.). On February 6, 2010, debris flows produced in the Station burn area overtopped sediment-retention basins and damaged or destroyed 46 homes in La Crescenta, Calif. These events provide sobering examples of the threat that post-fire debris flows pose to lives, properties, infrastructure, and important natural resources within and downstream of recently burned steeplands.

Wildfire causes numerous changes to the vegetative characteristics and physical and chemical properties of the soil within a burn area. Reduction in vegetation cover on hillslopes increases soil exposure to erosion during rainfall and runoff. Wildfire has also been demonstrated to increase the rate of runoff production by enhancing hydrophobicity in soils through chemical changes and by introducing ash into the soil column (Shakesby and Doerr, 2006; Gabet and Sternberg, 2008; Larsen and others; 2009). These changes ultimately contribute to increases in the rate of production of runoff and sediment during rainfall. The enhanced runoff response permits the initiation of floods and debris flows even during relatively minor rainstorms (Shakesby and Doerr, 2006; Cannon and others, 2008). Post-fire debris-flow hazards further increase in likelihood when the physical and chemical changes introduced 
during wildfire are combined with steep slopes and an abundant supply of sediment. Given the relatively steep terrain, severity of the wildfire, and proximity of local population and infrastructure, there is an elevated risk of post-fire debris-flow hazards within and downstream of the Mountain fire burn area. The purpose of this report is to provide a preliminary assessment of the likelihood and potential magnitude of post-fire debris flows in the area burned by the 2013 Mountain fire in Riverside County, Calif. We use empirical methods that have been previously applied in this region of southern California (for example, Cannon and others, 2007, 2009) to estimate (1) the probability of debris-flow occurrence in response to a storm with a 10-year (yr) recurrence interval, (2) the predicted volume of material transported and deposited by a debris flow in response to a storm with a 10 -yr recurrence interval, and (3) a combined relative hazard ranking that incorporates the results of the probability and volume models. We apply the models both at the scale of selected basins and in a spatially distributed manner along the drainage network within these basins.

\section{Physical Setting of the Mountain Burn Area}

The Mountain fire burned 111.4 square kilometers (27,350 acres) of mountainous terrain in Riverside County southwest of Palm Springs, Calif. (inciweb.org, 2013) from July 15th through July 30th, 2013 (fig. 1). The communities most affected by this event include those inhabiting the rural areas of the Agua Caliente Band of Cahuilla Indians reservation, the town of Mountain Center, and those occupying the land adjacent to Apple Canyon Road and Bonita Vista Road. Nearby communities and features outside the burnt perimeter include Palm Springs, Idyllwild, Pine Cove, Fern Valley, and Lake Hemet. The Mountain fire damaged or destroyed 23 structures and cost an estimated \$25.8 million to contain.

The Mountain burn area occupies mostly steep mountainous terrain, where elevations range from 377 meters $(\mathrm{m})$ to $2,837 \mathrm{~m}$ with an average slope of 45 percent. The rock type in the burn area is predominantly tonalite and schist, with smaller sections containing sandstone and quartz diorite (Jennings and Strand, 1969). Pre-fire vegetation consisted primarily of chaparral with lesser extents of fir, oak, and pine at higher elevations. A little over half of the area was burned at moderate (49 percent) and high (1.3 percent) severity (fig. 2) (Remote Sensing Applications Center, 2013). Areas of moderate and high burn severities fall primarily in the central portion of the burn area where the topography contains steeper slopes and more dense vegetation. The eastern extent in the vicinity of the Agua Caliente Indian Reservation was burned primarily at low severity.

The Mountain burn area is located in inland Riverside County and has generally lesser rainfall than other debris-flow prone locations, such as the San Gabriel, San Bernardino or Santa Monica mountains. Precipitation-frequency estimates for the burn area indicate that there is 10 percent likelihood in any given year (that is, a 10 -yr storm event) that 30 -minute (min) rainfall accumulations within the burn area will range between 18.6 millimeters $(\mathrm{mm})$ and $28.1 \mathrm{~mm}(0.7$ and 1.1 inches $)$ (Bonnin and others, 2006). These estimates suggest that a 10-year recurrence interval is likely to produce rainfall rates that have been observed to initiate post-fire debris flows in the region (Cannon and others, 2008; Staley and others, in press). We selected this storm frequency and magnitude as it represents a relatively large magnitude (in terms of total accumulation and peak storm intensities), but still somewhat common rainstorm. 


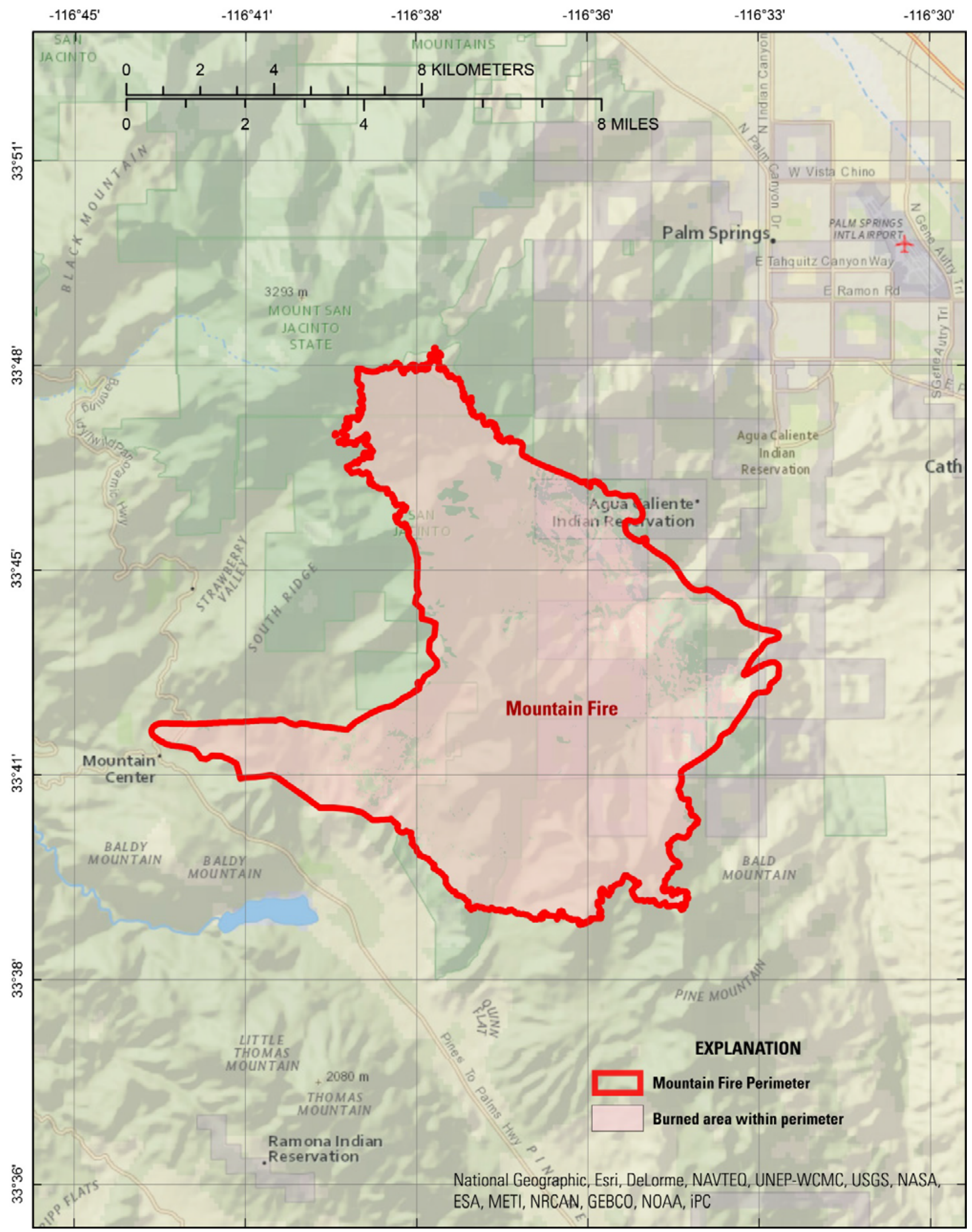

Figure 1. Overview map of the Mountain fire burn area near Palm Springs, California. 


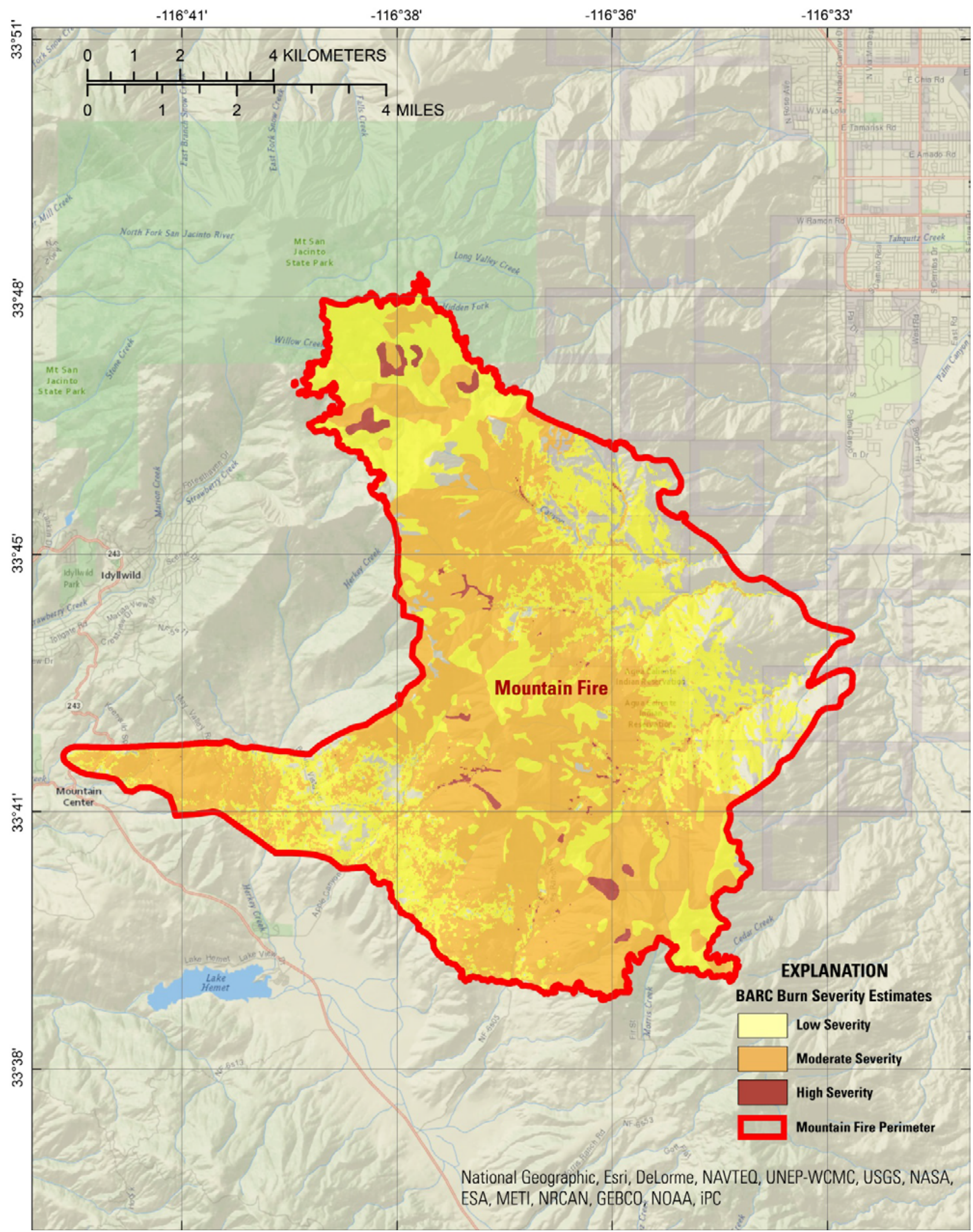

Figure 2. Burned Area Reflectance Classification (BARC) burn severity map of the Mountain fire burn area near Palm Springs, California. 


\section{Methods Used To Estimate Debris-Flow Hazards}

The preliminary hazard assessment relies upon two empirical models to estimate the probability, volume, and combined relative hazard ranking of debris flows for selected drainage basins within the Mountain fire. In this case, we use a rainstorm with a 10 -yr recurrence interval for the design storm. The empirical models are based upon historical debris-flow occurrence data, rainfall storm conditions, terrain and soils information, and burn severity data from recently burned areas in southern California. The probability database consists of 1,748 records from 20 burn areas from the years 2003-2010, and the volume database consists of 76 records from 13 burn areas from the years 1965-2010 (Gartner, 2013, U.S. Geological Survey, unpublished data).

In this study, we estimated the post-fire debris-flow probability, volume, and combined hazards both at the drainage-basin scale and in a spatially distributed manner along the drainage network within each basin. Basin outlets were identified for 14 drainage basins, and the characteristics of their upslope areas were calculated using a geographic information system (GIS). Debris-flow probability and volume were estimated for each basin outlet as well as along the upstream drainage networks (pixels where the contributing area is greater than or equal to 0.02 square kilometers $\left[\mathrm{km}^{2}\right]$ ) using a method that has been applied in recently burned areas (for example, Tillery and others, 2012; Verdin and others, 2012; Tillery and others, 2013). Estimates of debris-flow probability and volume were obtained for every 10-m pixel along the drainage network (plates 1 and 2) as a function of the distribution of independent variables upstream from each pixel. The technique used here allows for a view of how probability and volume estimates are spatially distributed within the drainage basin.

Probability estimates are based upon a logistic regression model derived from a southernCalifornia-specific database (Rupert and others, 2008), updated in 2011 to include basin-response information from the fires of 2007-2010 (Susan Cannon, 2011, U.S. Geological Survey, unpublished data). This model is designed to predict the probability of debris-flow occurrence at a point along the drainage network in response to a given storm by combining the following two equations:

$$
P=e^{x} /\left(1+e^{x}\right)
$$

where:

$P$ is the probability of debris-flow occurrence in fractional form, and

$e^{x}$ is the exponential function where $e$ represents the mathematical constant 2.718.

Equation 2 is used to calculate $x$ :

$$
\begin{aligned}
& x=-5.22+(0.003 \times \text { ElevRange })+\left(0.008 \times H M 50_{p c t}\right)+\left(0.024 \times \text { bslp }_{p c t}\right)+ \\
&\left(-0.007 \times C C_{p c t}\right)+(0.105 \times \text { L30 })(2)
\end{aligned}
$$

where:

ElevRange is the range (maximum elevation-minimum elevation) of elevation values upstream of the point (in meters),

$H M 50_{p c t}$ is the percentage of the upstream watershed that was burned at high or moderate severity and has slope values in excess of 50 percent (in percent),

$b s l p_{p c t}$ is the average gradient of the burned upslope of the point (in percent),

$C C_{p c t}$ is the average clay content of the soils in the basin (in percent) (Schwartz and Alexander, 1995), and

$i 30$ is the average upslope 30 -min rainfall intensity for the design storm.

In this case, we use the 30-min rainfall IQMQMWW for a 10-yr recurrence interval storm (in

$\mathrm{mm}$ ). Probabilities predicted by the equation potentially range from 0 (least likely) to 100 percent (most 
likely). The predicted probabilities are assigned to 1 of 5 equal (20 percent) interval classes for cartographic display.

Debris-flow volumes both at the basin outlet and along the drainage network are predicted using a multiple linear regression model (Gartner and others, 2008), which have been applied in nearby southern California burn areas between 2007 and 2009 (for example, Cannon and others, 2007; Cannon and DeGraff, 2009). This model is used to estimate the volume of material that could issue from a point along the drainage network in response to a storm of a given rainfall intensity. This model was based upon volume estimates from 53 debris-flow-producing drainage basins in 7 burn areas in southern California and follows the equation:

$$
\ln V=3.10+(0.46 \times \sqrt{i 15})+\left(0.30 \times \log \left(h m 50_{k m}\right)\right)+(0.17 \times \sqrt{\text { ElevRange }}
$$

where:

ElevRange is the range (maximum elevation-minimum elevation) of elevation values within the upstream watershed (in meters),

$h m 50_{k m}$ is the area upstream of the calculation point that was burned at high or moderate severity and has slope values in excess of 50 percent $\left(\mathrm{in}^{2} \mathrm{~km}^{2}\right.$ ), and

$i 15$ is the spatially-average peak 15 -min rainfall intensity for the design storm in the upstream watershed.

In this case, we use the 15-min rainfall intensity for a 10-yr recurrence interval storm (in $\mathrm{mm}$ ). Volume estimates were classified in order of magnitude scale ranges $0-1,000 \mathrm{~m}^{3}, 1,000-10,000 \mathrm{~m}^{3}$, $10,000-100,000 \mathrm{~m}^{3}$, and greater than $100,000 \mathrm{~m}^{3}$ for cartographic display.

\section{Debris-Flow Hazard Assessment}

We calculated the probability, predicted volume, and combined hazard at the outlet of 14 drainage basins and their drainage networks located within the Mountain burn area. For the lumped model, drainage basin areas range from $0.8-25.7 \mathrm{~km}^{2}$. Basin outlet locations, morphometric variables, rainfall characteristics, and model predictions are listed in table 1. Debris-flow probability, volume, and combined-hazards values represent the estimates at the outlet of each drainage basin and for each pixel along the drainage network. 
Table 1. Basin outlet locations (UTM Zone 11 NAD83, Meters), morphometric variables, rainfall characteristics, and model predictions for the 14 defined watersheds in the Mountain burn area.

[km², square kilometers; $\mathrm{m}$, meters; $\mathrm{mm} / \mathrm{hr}$, millimeters per hour; $\mathrm{mm}$, millimeters; $\mathrm{m}^{3}$, cubic meters]

\begin{tabular}{|c|c|c|c|c|c|c|c|c|c|c|c|c|c|}
\hline $\begin{array}{c}\text { Basin } \\
\text { ID }\end{array}$ & $\begin{array}{c}\text { Basin } \\
\text { area } \\
\left(\mathrm{km}^{2}\right)\end{array}$ & $\begin{array}{l}\text { Basin } \\
\text { outlet } \\
\text { easting } \\
\text { (m) }\end{array}$ & $\begin{array}{l}\text { Basin } \\
\text { outlet } \\
\text { northing } \\
\text { (m) }\end{array}$ & $\begin{array}{l}\text { Elevation } \\
\text { range } \\
(\mathrm{m})\end{array}$ & $\begin{array}{l}\text { Average } \\
\text { burned } \\
\text { area } \\
\text { gradient } \\
(\%)\end{array}$ & $\begin{array}{c}\text { Area of } \\
\text { moderate or } \\
\text { high severity } \\
\text { with slopes } \\
\geq 50 \%\left(\mathrm{~km}^{2}\right)\end{array}$ & $\begin{array}{c}\text { Area of } \\
\text { moderate or } \\
\text { high } \\
\text { severity } \\
\text { with slopes } \\
\geq 50 \%(\%)\end{array}$ & $\begin{array}{c}\text { Average } \\
\text { clay } \\
\text { content } \\
(\%)\end{array}$ & $\begin{array}{c}\text { 10-year } \\
\text { peak } \\
\text { 15-minute } \\
\text { intensity } \\
(\mathrm{mm} / \mathrm{hr})\end{array}$ & $\begin{array}{l}\text { 10-year } \\
30 \text {-minute } \\
\text { rainfall } \\
\text { accumulation } \\
(\mathrm{mm})\end{array}$ & $\begin{array}{l}\text { Probability } \\
\text { of debris } \\
\text { flow }\end{array}$ & $\begin{array}{l}\text { Predicted } \\
\text { volume } \\
\left(\mathrm{m}^{3}\right)\end{array}$ & $\begin{array}{c}\text { Combined } \\
\text { relative } \\
\text { hazard } \\
\text { ranking }\end{array}$ \\
\hline 1 & 18.81 & 541633 & 3735763 & 1,635 & 62.2 & 3.60 & $19.1 \%$ & 10.8 & 64 & 24 & $80-100 \%$ & $>100,000$ & 9 \\
\hline 2 & 22.05 & 541764 & 3734603 & 2,309 & 57.6 & 7.16 & $32.5 \%$ & 12.3 & 62 & 23 & $80-100 \%$ & $>100,000$ & 9 \\
\hline 3 & 22.15 & 542674 & 3733224 & 2,430 & 55.4 & 8.19 & $37.0 \%$ & 12.1 & 59 & 22 & $80-100 \%$ & $>100,000$ & 9 \\
\hline 4 & 0.99 & 535673 & 3738804 & 327 & 31.9 & 0.42 & $41.9 \%$ & 10.2 & 53 & 20 & $80-100 \%$ & $>100,000$ & 9 \\
\hline 5 & 3.92 & 532751 & 3723255 & 614 & 37.4 & 2.12 & $54.0 \%$ & 12.7 & 54 & 21 & $40-60 \%$ & $>100,000$ & 7 \\
\hline 6 & 1.58 & 532533 & 3725784 & 183 & 38.1 & 0.82 & $51.9 \%$ & 12.2 & 58 & 21 & $60-80 \%$ & $>100,000$ & 8 \\
\hline 7 & 2.98 & 531832 & 3726104 & 616 & 19.8 & 0.08 & $2.8 \%$ & 12.2 & 59 & 22 & $20-40 \%$ & $10,000-100,000$ & 5 \\
\hline 8 & 10.31 & 531353 & 3726594 & 966 & 16.6 & 0.00 & $0.0 \%$ & 10.0 & 61 & 22 & $0-20 \%$ & $10,000-100,000$ & 3 \\
\hline 9 & 25.74 & 530913 & 3727023 & 1,348 & 41.0 & 2.97 & $11.5 \%$ & 13.0 & 57 & 21 & $60-80 \%$ & $>100,000$ & 8 \\
\hline 10 & 0.85 & 530131 & 3727155 & 201 & 19.8 & 0.06 & $6.6 \%$ & 14.3 & 60 & 22 & $20-40 \%$ & $10,000-100,000$ & 5 \\
\hline 11 & 24.64 & 529582 & 3726605 & 2,058 & 22.3 & 0.57 & $2.3 \%$ & 12.2 & 60 & 22 & $60-80 \%$ & $>100,000$ & 8 \\
\hline 12 & 2.98 & 526522 & 3729095 & 537 & 15.6 & 0.01 & $0.2 \%$ & 11.0 & 61 & 22 & $0-20 \%$ & $10,000-100,000$ & 3 \\
\hline 13 & 3.51 & 525794 & 3729484 & 894 & 20.4 & 0.02 & $0.6 \%$ & 12.8 & 61 & 23 & $20-40 \%$ & $10,000-100,000$ & 5 \\
\hline 14 & 11.68 & 525433 & 3729864 & 877 & 14.0 & 0.00 & $0.0 \%$ & 12.8 & 62 & 23 & $0-20 \%$ & $10,000-100,000$ & 3 \\
\hline
\end{tabular}




\section{Debris-Flow Probability Estimates}

Overall, the basin-scale model predicts high probabilities of debris flow throughout most of the burn area in response to a 10-yr, 30-min rainstorm (plate 1). High probability values result from the steepness of burned slopes and relatively high burn severities, particularly in the eastern portion of the burn area. Three of the 14 defined basins were identified as having a 0-20 percent likelihood of debris flow during the design storm. These basins (Basins 8, 12 and 14) occupy the lower elevation terrain east of Mountain Center, Calif. Three basins (Basins 7, 10 and 13) were determined to have a 20-40 percent probability of debris-flow occurrence, while one basin (Basin 5) was calculated as having a 40-60 percent probability. Three basins were identified as having a 60-80 percent debris flow probability: a small, unnamed watershed northwest of Fobes Canyon (Basin 6), Apple Canyon (Basin 9), and Herkey Creek (Basin 11). Probabilities increased significantly in the steeper terrain composing the western portion of the burn area. Basins 1, 2, 3, and 4 were all calculated as having a 80-100 percent likelihood of debris-flow occurrence. These basins are located immediately upstream of the Agua Caliente Indian Reservation and directly affect Tahquitz Creek (Basin 4), Andreas Canyon (Basin 1), Murray Canyon (Basin 2), and West Fork Palm Canyon (Basin 3).

The spatially distributed application of the probability model may be used to identify probability of debris flow occurrence for specific stream reaches. This model determined that in 7 of the 14 basins (Basins 1, 2, 3, 4, 6, 9, and 11), probabilities exceeded 60 percent for many of the stream segments extending high into basin headwaters. This suggests significant debris-flow hazard in steep headwater areas (table 2). Tahquitz Creek (Basin 4) has 34.1 percent of its total stream length with probabilities greater than 60 percent. Andreas Canyon (Basin 4) was found to have 24.3 percent of its stream length with probabilities greater than 60 percent, and Murray Canyon (Basin 2) had 21.8 percent of its stream length with probabilities greater than 60 percent. 
Table 2. Summary of the total percentage of stream length per basin within each probability, volume, and combined hazard ranking for the Mountain burn area.

$\left[\mathrm{m}^{3}\right.$, cubic meters]

\begin{tabular}{|c|c|c|c|c|c|c|c|c|c|c|c|c|}
\hline \multirow{2}{*}{$\begin{array}{l}\text { Basin } \\
\text { ID }\end{array}$} & \multicolumn{5}{|c|}{ Percent of total stream length with probabilities: } & \multicolumn{4}{|c|}{ Percent of total stream length with predicted volumes: } & \multicolumn{3}{|c|}{$\begin{array}{l}\text { Percent of total stream } \\
\text { length within hazard class: }\end{array}$} \\
\hline & $0-20 \%$ & $20-40 \%$ & $40-60 \%$ & $60-80 \%$ & $80-100 \%$ & $\begin{array}{c}0-1,000 \\
\mathrm{~m}^{3}\end{array}$ & $\begin{array}{c}1000-10,000 \\
\mathrm{~m}^{3}\end{array}$ & $\begin{array}{c}10,000-100,000 \\
\mathrm{~m}^{3} \\
\end{array}$ & $\begin{array}{c}>100,000 \\
\mathrm{~m}^{3}\end{array}$ & Low & Moderate & High \\
\hline 1 & $10.7 \%$ & $32.0 \%$ & $23.3 \%$ & $14.0 \%$ & $20.1 \%$ & $28.6 \%$ & $20.9 \%$ & $28.4 \%$ & $22.2 \%$ & $11.6 \%$ & $64.1 \%$ & $24.3 \%$ \\
\hline 2 & $17.6 \%$ & $39.0 \%$ & $19.1 \%$ & $8.2 \%$ & $16.1 \%$ & $16.3 \%$ & $25.7 \%$ & $36.8 \%$ & $21.2 \%$ & $17.5 \%$ & $60.9 \%$ & $21.6 \%$ \\
\hline 3 & $26.1 \%$ & $32.3 \%$ & $19.8 \%$ & $9.0 \%$ & $12.8 \%$ & $17.3 \%$ & $25.5 \%$ & $37.5 \%$ & $19.7 \%$ & $26.3 \%$ & $53.8 \%$ & $19.9 \%$ \\
\hline 4 & $50.2 \%$ & $29.6 \%$ & $11.0 \%$ & $6.1 \%$ & $3.0 \%$ & $59.4 \%$ & $18.1 \%$ & $12.3 \%$ & $10.2 \%$ & $50.6 \%$ & $40.5 \%$ & $9.0 \%$ \\
\hline 5 & $42.6 \%$ & $32.7 \%$ & $24.5 \%$ & $0.1 \%$ & $0.0 \%$ & $13.7 \%$ & $34.7 \%$ & $36.8 \%$ & $14.7 \%$ & $47.3 \%$ & $52.6 \%$ & $0.1 \%$ \\
\hline 6 & $44.0 \%$ & $30.9 \%$ & $12.8 \%$ & $12.3 \%$ & $0.0 \%$ & $5.8 \%$ & $41.3 \%$ & $36.0 \%$ & $16.9 \%$ & $38.4 \%$ & $48.7 \%$ & $12.9 \%$ \\
\hline 7 & $89.0 \%$ & $11.0 \%$ & $0.0 \%$ & $0.0 \%$ & $0.0 \%$ & $34.7 \%$ & $39.8 \%$ & $25.5 \%$ & $0.0 \%$ & $70.8 \%$ & $29.2 \%$ & $0.0 \%$ \\
\hline 8 & $100.0 \%$ & $0.0 \%$ & $0.0 \%$ & $0.0 \%$ & $0.0 \%$ & $50.7 \%$ & $49.3 \%$ & $0.0 \%$ & $0.0 \%$ & $100.0 \%$ & $0.0 \%$ & $0.0 \%$ \\
\hline 9 & $29.3 \%$ & $35.7 \%$ & $23.3 \%$ & $11.6 \%$ & $0.0 \%$ & $14.8 \%$ & $28.5 \%$ & $41.8 \%$ & $14.9 \%$ & $30.7 \%$ & $58.5 \%$ & $10.8 \%$ \\
\hline 10 & $88.2 \%$ & $11.8 \%$ & $0.0 \%$ & $0.0 \%$ & $0.0 \%$ & $59.2 \%$ & $7.9 \%$ & $33.0 \%$ & $0.0 \%$ & $63.9 \%$ & $36.1 \%$ & $0.0 \%$ \\
\hline 11 & $44.3 \%$ & $19.7 \%$ & $10.2 \%$ & $25.7 \%$ & $0.0 \%$ & $35.4 \%$ & $21.3 \%$ & $22.0 \%$ & $21.2 \%$ & $44.1 \%$ & $33.7 \%$ & $22.2 \%$ \\
\hline 12 & $100.0 \%$ & $0.0 \%$ & $0.0 \%$ & $0.0 \%$ & $0.0 \%$ & $69.5 \%$ & $30.5 \%$ & $0.0 \%$ & $0.0 \%$ & $100.0 \%$ & $0.0 \%$ & $0.0 \%$ \\
\hline 13 & $92.6 \%$ & $7.4 \%$ & $0.0 \%$ & $0.0 \%$ & $0.0 \%$ & $48.5 \%$ & $33.1 \%$ & $18.4 \%$ & $0.0 \%$ & $81.4 \%$ & $18.6 \%$ & $0.0 \%$ \\
\hline 14 & $100.0 \%$ & $0.0 \%$ & $0.0 \%$ & $0.0 \%$ & $0.0 \%$ & $52.9 \%$ & $47.1 \%$ & $0.0 \%$ & $0.0 \%$ & $100.0 \%$ & $0.0 \%$ & $0.0 \%$ \\
\hline
\end{tabular}




\section{Debris-Flow Volume Estimates}

The basin-scale volume model predicted that the consequences of debris-flow occurrence are potentially quite high (plate 2) throughout the burn area. We estimated that 8 of the 14 basins could produce debris flows with volumes in excess of $100,000 \mathrm{~m}^{3}$. These basins include Tahquitz Creek (Basin 4), Andreas Canyon (Basin 1), Murray Canyon (Basin 2), West Fork Palm Canyon (Basin 3), Fobes Canyon (Basin 5), a small, unnamed watershed northwest of Fobes Canyon (Basin 6), Apple Canyon (Basin 9), and Herkey Creek (Basin 11). Three of the 14 basins were identified as having debris flows with volumes ranging from 10,000-100,000 $\mathrm{m}^{3}$. These areas include an unnamed Basin 7, an unnamed basin above Camp Roosevelt (Basin 10), and Coldwater Creek (Basin 13). The remaining three basins (Basins 8, 12 and 14) were identified as having a predicted debris-flow volume less than $1,000 \mathrm{~m}^{3}$. The spatially distributed volume model identified that large (greater than $10,000 \mathrm{~m}^{3}$ ) debris flows were possible in a majority (greater than 50 percent of total stream length) of stream segments in the following basins: Tahquitz Creek (Basin 4), Andreas Canyon (Basin 1), Murray Canyon (Basin 2), Fobes Canyon (Basin 5), and Apple Canyon (Basin 9) (table 2).

\section{Combined Relative Debris-Flow Hazard Rankings}

We combined the results of the probability and the volume maps following the methods of Cannon and others (2010) to obtain an estimate of the combined relative hazard of the drainage basins defined for the Mountain fire (plate 3). Eight of the basins were calculated to have the highest combined hazard ranking (cumulative score greater than or equal to 7 out of a possible 9) which indicates that these basins are likely to produce large debris flows in response to the design rainstorms. The basins within the highest hazard classification include Andreas Canyon (Basin 1), Murray Canyon (Basin 2) and West Fork Palm Canyon (Basin 3) and Tahquitz Creek (Basin 4), all of which had the maximum possible hazard ranking (score of 9 out of a possible 9). Other basins in the "high" hazard ranking include Fobes Canyon (Basin 5), unnamed Basin 6, Apple Canyon (Basin 9) and Herkey Creek (Basin 11). Three drainage basins were identified as having a moderate combined hazard (cumulative score from 4-6 out of a possible 9). This hazard ranking includes unnamed Basin 7, an unnamed basin above Camp Roosevelt (Basin 10) and Coldwater Creek (Basin 13). The remaining basins (Basins 8, 12, and 14) were calculated as having the lowest combined hazard rankings (score of 3 out of a possible 9). The spatially distributed hazard ranking identified that stream segments with the highest possible combined hazard rankings occurred upstream of the pour point in the following basins: Tahquitz Creek (Basin 1), Andreas Canyon (Basin 2), Murray Canyon (Basin 3), Fobes Canyon (Basin 5), Apple Canyon (Basin 9), and Herkey Creek (Basin 11) (table 2).

\section{Limitations of Hazard Assessments}

This assessment used a 10-yr recurrence interval storm to predict the probability, volume, and combined relative hazard of debris flows in basins burned by the 2013 Mountain fire near Palm Springs, Calif. Differences in model predictions and actual debris-flow occurrence will arise with differences in actual storm duration and intensity. In addition, this study relies upon readily available geospatial data, the accuracy and precision of which may influence the estimated likelihood and magnitude of post-fire debris flows. However, local conditions (such as debris supply) certainly influence both the probability and volume of debris flows. Unfortunately, locally specific data is not presently available at the spatial scale of the post-fire debris-flow hazard assessment. As such, local conditions that are not constrained by the model may serve to dramatically increase or decrease the probability and(or) volume of a debris 
flow at a basin outlet. The input geospatial data are also subject to error based upon mapping resolution, elevation interpolation techniques, and mapping and(or) classification methods. Finally, this assessment is specific to debris-flow hazards; hazards from flash-flooding are not described in this study and may be significant.

This assessment also characterizes potential debris-flow hazards at a static point in time immediately following wildfire. Studies of post-fire debris flows in southern California and the intermountain western United States have indicated that debris-flow activity in recently burned areas typically occurs within 2 yr of wildfire (Cannon and Gartner, 2005; Cannon and others, 2008; Gartner and others, 2008; Cannon and others, 2009). As vegetation cover and soil properties return to pre-fire conditions, the threat of debris-flow activity decreases with time elapsed since wildfire. Conversely, the hazards from flash-flooding may persist for several years after wildfire.

Finally, this work is preliminary and is subject to revision. It is being provided due to the need for timely "best science" information. The assessment is provided on the condition that neither the U.S. Geological Survey nor the Unites States Government may be held liable for any damages resulting from the authorized or unauthorized use of the assessment.

\section{Summary and Conclusions}

This assessment characterizes the post-fire debris-flow hazards that may exist within and below the 2013 Mountain fire near Palm Springs, Calif. We use geospatial data related to basin morphometry, burn severity, soil properties, and rainfall characteristics to estimate the probability and predicted volume of debris flows that may occur in response to a 10 -yr recurrence interval rainstorm. We have identified that probabilities of debris-flow occurrence in response to the design rainstorm are high throughout the burn area, with 6 of the 14 defined basins having a probability of debris flow greater than 60 percent. The volume model predicts that potential debris flows may be large: 8 of the 14 basins were identified as capable of producing debris flows with volumes greater than $100,000 \mathrm{~m}^{3}$. Combining the probability and volume models into a combined hazard ranking indicates that 8 basins were of the greatest threat of post-fire debris-flow activity, obtaining a score greater than or equal to 7 out of possible 9.

High and moderate relative hazard rankings identified by the spatially distributed models indicate a significant possibility of debris-flow impact to homes, building, roads, bridges, culverts, and reservoirs located both within and downstream of the burn area. We recommend that residents remain vigilant and take responsible actions to prevent injury or loss of life from post-fire debris flows and flash floods that may occur in response to high-intensity rainfall during short-lived summer convective thunderstorms and longer-duration winter storms.

\section{References Cited}

Bonnin, G.M., Martin, D., Lin, B., Parzybok, T., Yekta, M., and Riley, D., 2006, Precipitation frequency atlas of the United States: Silver Spring, Md., National Weather Service, National Oceanic and Atmospheric Administration (NOAA) atlas 14, v. 1, version 5, accessed July 30, 2013, at http://hdsc.nws.noaa.gov/hdsc/pfds/.

Campbell, R.H, 1975, Soil slips, debris flows, and rainstorms in the Santa Monica mountains and vicinity, southern California: U.S. Geological Survey Professional Paper 851, 55 p.

Cannon, S.H., Boldt, E.M., Kean, J.W., Laber, J.L., and Staley, D.M., 2010, Relations between rainfall and postfire debris-flow and flood magnitudes for emergency-response planning, San Gabriel 
Mountains, southern California: U.S. Geological Survey Open-File Report 2010-1039, 31 p., available at $h t t p: / / p u b s . u s g s . g o v / o f / 2010 / 1039 /$.

Cannon, S.H., Boldt, E.M., Laber, J.L., Kean, J.W., and Staley, D.M., 2011, Rainfall intensityDuration thresholds for postfire debris-flow emergency-response planning: Natural Hazards, v. 59, no. 1, p. 209-236.

Cannon, S.H., and DeGraff, J., 2009, The increasing wildfire and post-fire debris-flow threat in western USA, and implications for consequences of climate change, chap. 9 of Sassa, K. and Canuti, P., eds., Landslides: Disaster Risk Reduction: Springer, Berlin, p. 177-190.

Cannon, S.H., and Gartner, J.E., 2005, Wildfire-related debris flow from a hazards perspective, chap. 15 of Jakob, M., and Hungr, O., eds., Debris-flow hazards and related phenomena: Chichester, U.K., Springer-Praxis Books in Geophysical Sciences, p. 321-344.

Cannon, S.H., Gartner, J.E., Michael, J.A., Bauer, M.A., Stitt, S.C., Knifong, D.L., McNamara, B.J., and Roque, Y.M., 2007, Emergency assessment of debris-flow hazards from basins burned by the 2007 Buckweed fire, Los Angeles County, southern California: U.S. Geological Survey Open-File Report 2007-1414,1 sheet, at http://pubs.usgs.gov/of/2007/1414/.

Cannon, S.H., Gartner, J.E., Rupert, M.G., Michael, J.A., Staley, D.M., and Worstell, B.B., 2009, Emergency assessment of postfire debris-flow hazards for the 2009 Station Fire, San Gabriel Mountains, southern California: U.S. Geological Survey Open File Report 2008-1370, 20 p., http://pubs.usgs.gov/of/2008/1370/.

Cannon, S.H., Gartner, J.E., Wilson, R., Bowers, J., and Laber, J., 2008, Storm rainfall conditions for floods and debris flows from recently burned areas in southwestern Colorado and southern California: Geomorphology, v. 96, no. 3-4, p. 250-269.

Eaton, E.C., 1935, Flood and erosion control problems and their solution: Proceedings of the American Society of Civil Engineers, v. 62, no. 8, p. 1,302-1,362.

Gabet, E., and Sternberg, P., 2008, The effects of vegetative ash on infiltration capacity, sediment transport, and the generation of progressively bulked debris flows: Geomorphology, v. 10, no. 4, p. 666-673.

Gartner, J.E., Cannon, S.H., Santi, P., and Dewolfe, V., 2008, Empirical models to predict the volumes of debris flows generated by recently burned basins in the western U.S.: Geomorphology, v., 96, no. 3-4, p. 339-354.

inciweb.org, 2013, Mountain fire: InciWeb, accessed July 2013, at http://www.inciweb.org/incident/3516/\#.

Jennings, C.W., and Strand, R.G., 1969, Geologic map of California—Los Angeles Sheet: Sacramento, Calif., California Division of Mines and Geology, 1:250,000.

Kean, J.W., Staley, D.M., and Cannon, S.H., 2011, In situ measurements of post-fire debris flows in southern California - Comparisons of the timing and magnitude of 24 debris-flow events with rainfall and soil moisture conditions: Journal of Geophysical Research, v. 116, F4:F04019.

Larsen, I.J., MacDonald, L.H., Brown, E., Rough, D., Welsh, M.J., Pietraszek, J.H., Libohova, Z., de Dios Benavides-Solorio, J., and Schaffrath, K., 2009, Causes of post-fire runoff and erosion-Water repellency, cover, or soil sealing?: Soil Science Society of America Journal, v. 73, no. 4, p. 1,3931,407 .

McPhee, J.A., 1989, The control of nature: New York, Farrar, Straus and Giroux, 272p.

Remote Sensing Applications Center, 2013, BAER imagery support data download, USFS Region 5:

U.S. Department of Agriculture Forest Service, accessed July 2013, at http://activefiremaps.fs.fed.us/baer/download.php. 
Rupert, M.G., Cannon, S.H., Gartner, J.E., Michael, J.A., and Helsel, D.R., 2008, Using logistic regression to predict the probability of debris flows in areas burned by wildfires, southern California, 2003-2006: U.S. Geological Survey Open-File Report 2008-1370, 20 p., http://pubs.usgs.gov/of/2008/1370/.

Schwartz, G.E., and Alexander, R.B., 1995, Soils data for the conterminous United States derived from the NRCS State Soil Geographic (STATSGO) Database: U.S. Geological Survey Open-File Report 95-449, accessed July 2013, at http://water.usgs.gov/GIS/metadata/usgswrd/XML/ussoils.xml.

Shakesby, R., and Doerr, S., 2006, Wildfire as a hydrological and geomorphological agent: EarthScience Reviews, v. 74, no. 3-4, p. 269-307.

Staley, D.M., Kean, J.W., Cannon, S.H., Schmidt, K.M., and Laber, J.L., in press, Objective definition of rainfall intensity-Duration thresholds for the initiation of post-fire debris flows in southern California: Landslides, p. 1-16.

Tillery, A.C., and Matherne, A.M., 2013, Postwildfire debris-flow hazard assessment of the area burned by the 2012 Little Bear fire, south-central New Mexico: U.S. Geological Survey Open File Report 2013-1108, 15 p., 3 plates, at http://pubs.usgs.gov/of/2013/1108/.

Tillery, A.C., Matherne, A.M., and Verdin K.L., 2012, Estimated probability of postwildfire debris flows in the 2012 Whitewater-Baldy Fire burn area, southwestern New Mexico: U.S. Geological Survey Open-File Report 2012-1188, 11 p., 3 plates, at http://pubs.usgs.gov/of/2012/1188/.

Verdin, K.L., Dupree, J.A., and Elliot, J.G., 2012 probability and volume of potential postwildfire debris flows in the 2012 Waldo Canyon burn area near Colorado Springs, Colorado: U.S. Geological Survey Open-File Report 2012-1158, 8 p., at http://pubs.usgs.gov/of/2012/1158/. 